\title{
Effects of Maternal Diabetes on Fetal Rat Lung Ion Transport Contribution of Alveolar and Bronchiolar Epithelial Cells to $\mathrm{Na}^{+}, \mathrm{K}^{+}$-ATPase Expression
}

Emese Pinter, John A. Peyman, ${ }^{\star}$ Kris Snow, James D. Jamieson, ${ }^{\star}$ and Joseph B. Warshaw

Departments of Pediatrics and *Cell Biology, Yale University School of Medicine, New Haven, Connecticut 06510

\begin{abstract}
Fetuses of streptozotocin-induced diabetic rats exhibited delayed lung maturation and a $40 \%$ reduction in the steady-state level of lung $\mathrm{Na}^{+}, \mathrm{K}^{+}$-ATPase $\alpha 1$ subunit $\mathrm{mRNA}$ and $\mathrm{Na}^{+}, \mathrm{K}^{+}$-ATPase activity at $21 \mathrm{~d}$ of gestation. In in situ hybridization experiments the signal specific for $\mathrm{Na}^{+}$-pump $\alpha 1$ subunit message was strongest above columnar epithelial cells of air-conducting structures. Strong labeling was also present above cuboidal cells lining the forming alveoli, but not above mesenchymal cells. Immunocytochemical localization of the protein paralleled the distribution of the mRNA. Mesenchymal cells were more abundant in fetal lungs of diabetic mothers, and thus the decreased overall levels of $\mathrm{Na}^{+}, \mathrm{K}^{+}$-ATPase may result from the observed morphological pulmonary immaturity. One day after birth there was no apparent difference in lung morphology at the light microscopic level, in the localization or the steady-state level of $\mathrm{Na}^{+}, \mathrm{K}^{+}$-ATPase $\alpha 1$ isoform mRNA, or in enzyme activity. $\mathrm{Na}^{+}, \mathrm{K}^{+}$-ATPase has a likely role in the active phase of fluid absorption in the airways of newborns before the onset of breathing. Decreased fluid clearance and lack of thinning of the lung's connective tissue may contribute to the increased risk for respiratory distress in infants of diabetic mothers. (J. Clin. Invest. 1991. 87:821-830.) Key words: $\mathrm{Na}^{+}, \mathrm{K}^{+}=$ATPase $\bullet$ sodium pump • infant of diabetic mother $\bullet$ lung maturation
\end{abstract}

\section{Introduction}

Infants of diabetic mothers exhibit a striking increase in the incidence of hyaline membrane disease $(1,2)$. This has been related to delayed morphological and biochemical maturation of lung in diabetic pregnancy (3-7). Lungs of streptozotocininduced diabetic rats synthesize decreased amounts of phosphatidylcholine, which is the major surfactant phospholipid (7-12), and are underdeveloped morphologically. These changes are characterized by decreased numbers of alveolar type II cells which are the sites of surfactant synthesis, and by a delay in the normal alveolarization of the fetal lung that is necessary for postnatal respiration (7). An important aspect of the maturation of the lung involves the ability to remove fluid from the potential air spaces at birth to facilitate gas exchange

Address reprint requests to Dr. Joseph B. Warshaw, Department of Pediatrics, Yale University School of Medicine, P.O. Box 3333, New Haven, CT 06510.

Received for publication 20 February 1990 and in revised form 17 September 1990.

J. Clin. Invest.

(C) The American Society for Clinical Investigation, Inc.

$0021-9738 / 91 / 03 / 0821 / 10 \$ 2.00$

Volume 87, March 1991, 821-830
(13-16). The trigger for alveolar fluid clearance is still unknown, but studies utilizing fetal lambs suggest that active ion transport across the pulmonary epithelial membrane facilitates lung fluid absorption at birth (17). $\mathrm{Na}^{+}, \mathrm{K}^{+}$-ATPase is an ubiquitous membrane protein which plays a central role in cellular homeostasis, is necessary for $\mathrm{Na}^{+}$-coupled transport of a variety of molecules, and has a role in cell division and differentiation (18-23). Observations that $\mathrm{Na}^{+}, \mathrm{K}^{+}$-ATPase $\alpha 1$-subunit and $\beta$-subunit mRNAs increase in abundance at birth support the hypothesis that this enzyme plays a role in perinatal pulmonary fluid absorption (24).

We have examined the influence of the maternal diabetic state on expression in the lung of the $\alpha 1$ isoform of $\mathrm{Na}^{+}, \mathrm{K}^{+}$-ATPase and of the activity of the $\mathrm{Na}^{+}, \mathrm{K}^{+}$-ATPase enzyme to determine the relationship between these levels and the maturation of fetal lung from diabetic mothers.

\section{Methods}

Induction of diabetes. Adult, virgin, female, Sprague-Dawley rats (Charles River Breeding Laboratories, Inc., Wilmington, MA) were injected under light ether anesthesia with $50 \mathrm{mg} / \mathrm{kg}$ streptozotocin (Sigma Chemical Co., St. Louis, MO) freshly dissolved in $5 \mathrm{mM}$ citrate

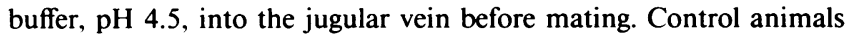
received an equivalent volume of buffered citrate solution. Serum glucose levels were determined by the glucose oxidase method, and only those diabetic animals were used whose serum glucose values were $>300 \mathrm{mg} / \mathrm{dl}$.

Animals. Fetuses were obtained from normal and diabetic rats with timed pregnancies. Animals were housed under normal laboratory conditions of $14 \mathrm{~h}$ daily illumination. The sperm-positive day was considered pregnancy day 1 . On pregnancy day 21 , pregnant normal and diabetic females were sacrificed by decapitation, and the fetuses were removed rapidly by hysterotomy and lungs were dissected out. The mean weight at delivery of the normal fetuses, in nine litters, $n=102$, was $3.90 \mathrm{~g} \pm 0.29 \mathrm{SEM}$, and the mean delivery weight of the fetuses of diabetic mothers, in eight litters, $n=89$, was $3.15 \mathrm{~g} \pm 0.86$. Pups of both normal and diabetic mothers were delivered vaginally on pregnancy day 22. The mean birth weight of the normal pups, in four litters, $n$ $=19$ was $6.14 \mathrm{~g} \pm 0.28 \mathrm{SEM}$, and the mean birth weight of the pups of diabetic mothers, in four litters, $n=26$, was $5.46 \mathrm{~g} \pm 0.61$ SEM. Because the diabetic mothers did not provide adequate colostrum and milk, the newborns of both normal and diabetic mothers were fed by normal nursing female rats, and they were sacrificed at $24 \mathrm{~h}$ by decapitation. Under these conditions the two groups experienced no difference in neonatal mortality. The mean blood glucose level of the normal mothers was $81 \mathrm{mg} / \mathrm{dl}$, and of their fetuses, $33 \mathrm{mg} / \mathrm{dl}$. The diabetic mothers' mean blood glucose level was $432 \mathrm{mg} / \mathrm{dl}$ and their fetuses' was $357 \mathrm{mg} / \mathrm{dl}$. We have shown previously that plasma insulin levels in fetuses of diabetics are low despite significant hyperglycemia. This has been attributed to islet cell exhaustion (8).

$\mathrm{Na}^{+}, \mathrm{K}^{+}$-ATPase enzyme activity. $\sim 200 \mathrm{mg}$ of lung tissue obtained from fetuses and neonates of normal and diabetic mothers was homogenized in $1 \mathrm{ml}$ of ice-cold $50 \mathrm{mM}$ Tris, $250 \mathrm{mM} \mathrm{NaCl}, \mathrm{pH} \mathrm{7.4,} \mathrm{at} 4^{\circ} \mathrm{C}$ by using six passes of a motor driven Teflon homogenizer operated at $2,300 \mathrm{rpm}$. The homogenate was then passed through two layers of gauze. The $\mathrm{Na}^{+}, \mathrm{K}^{+}$-ATPase activity was determined in $100 \mu \mathrm{l}$ of fresh 
lung homogenate by preincubating at $37^{\circ} \mathrm{C}$ in buffer with or without 2 $\mathrm{mM}$ ouabain. The results were corrected for spontaneous hydrolysis of ATP. A measure of the ouabain-sensitive $\mathrm{Na}^{+}, \mathrm{K}^{+}$-ATPase activity was obtained by determining the ouabain-inhibitable portion of the ATPase activity (25), which ranged from 12 to $20 \%$ of the total activity in different experiments, and was similar when samples were analyzed from lungs of fetuses of normal or diabetic mothers. Inorganic phosphate was measured by the method of Fiske and Subbarow (26). The specific activity of the enzyme was expressed as $\mathrm{mmol} \mathrm{P}_{\mathrm{i}} / \mathrm{mg}$ protein per $h$. Protein was estimated according to the method of Lowry et al. (27). The recovery of added dog kidney membrane-derived $\mathrm{Na}^{+}, \mathrm{K}^{+}$-ATPase (Sigma Chemical Co.) activity was determined in control experiments using four independent samples of fetal lung tissue, and the mean recovery from fetal lung homogenates from diabetic mothers was $77 \%$ of the recovery from homogenates of lung from normal mothers.

Northern blot analysis. Pooled lung samples (5-10 lungs per litter, three or four litters from normal and diabetic mothers) were immediately frozen in isopentane cooled in liquid nitrogen. Total cellular RNA was isolated from the tissue (28), further purified by two phenolchloroform extractions and two ethanol precipitations, and then redissolved in diethylpyrocarbonate-treated water containing $0.1 \%$ SDS (29). $20 \mu \mathrm{g}$ of RNA per lane was run on $23-\mathrm{cm}$-long $1 \%$ agarose-formaldehyde gels and transferred to Gene Screen nylon membrane. Blots were probed with $10^{6} \mathrm{cpm} / \mathrm{ml}$ of ${ }^{32} \mathrm{P}$-labeled rat $\mathrm{Na}^{+}, \mathrm{K}^{+}$-ATPase $\alpha 1$ full-length antisense cRNA probe and washed repeatedly with 0.1 $\times$ SSC containing $0.5 \%$ sodium dodecyl sulfate at $65^{\circ} \mathrm{C}$. Autoradiographs were made on Kodak XAR- 5 film with an intensifying screen at $-70^{\circ} \mathrm{C}$ and were quantitated by densitometry. A series of closelyspaced exposures was prepared in each experiment, and the grain density was seen to be roughly linear with time in the range used for densitometry. The rat $\mathrm{Na}^{+}, \mathrm{K}^{+}$-ATPase $\alpha 1$ subclone with a $2.5-\mathrm{kb}$ insert in pGEM-4 was kindly provided by E. J. Benz, Jr. and linearized with Nael (New England Biolabs, Beverly, MA), and a ${ }^{32}$ P-labeled, antisense-strand, positive probe was produced by transcription using $\mathrm{T} 7$ RNA polymerase (Stratagene) and [ $\left.\alpha^{32} \mathrm{P}\right]-\mathrm{CTP}$ (Amersham Corp., Arlington Heights, IL).

Morphometric analysis. Morphometric studies were conducted according the methods of Weibel (30). 10 randomly selected $5 \times 5 \mathrm{~mm}^{3}$ pieces of fetal lungs from each of 10 fetuses taken from three litters of normal and diabetic mothers were fixed overnight in $1.5 \%$ glutaraldehyde and $1.5 \%$ formaldehyde in $0.1 \mathrm{M}$ phosphate buffer $(\mathrm{pH} 7.4)$, dehydrated, and embedded in Araldite (EM bed 812, E. M. Sciences, Ft. Washington, PA). $0.5-\mu \mathrm{M}$ sections were stained with toluidine blue and an average of 10 photomicrographs were taken from sections representing each litter. The percent of lung surface occupied by bronchiolar epithelium, other cell types and air spaces was determined by point counting analysis (30). Experimental groups were compared by Student's $t$ test for independent values. Values with a $P<0.05$ were regarded as significant.

Immunocytochemistry. Day 21 fetal and day 1 neonatal lungs of diabetic and normal rat mothers and normal adult female kidney (used as control tissue) were cut into 5-mm cubes, quick-frozen in isopentane cooled in liquid nitrogen, and stored in liquid nitrogen until use. $10-\mu \mathrm{m}$ frozen sections were thaw-mounted on glass slides coated with Histostik (Accurate Chemical and Scientific Corp., New York, NY). The sections were air-dried for $2 \mathrm{~h}$, dehydrated in ethanol, and stored in sealed boxes at $-20^{\circ} \mathrm{C}$. A monoclonal mouse anti-rat $\mathrm{Na}^{+}, \mathrm{K}^{+}$-ATPase $\mathrm{NH}_{2}$-terminal peptide IgG antibody was provided by $\mathrm{K}$. Sweadner (31). The primary antibody was diluted 1:5 and was detected by the avidinbiotin peroxidase technique with a Vectastain $\mathrm{ABC}$ kit according to the instructions of the manufacturer (Vector Laboratories, Inc., Burlingame, CA). Nonspecific mouse monoclonal IgG was used at 1:5 dilution as a negative control antibody. Some sections were incubated directly with the secondary antibody without the preceding steps.

In situ hybridization. Frozen sections were prepared as described above for immunocytochemistry and pretreated according to the procedures of Cox et al. (32) and Awgulewitsch et al. (33). Sections were hybridized with ${ }^{35} \mathrm{~S}$-labeled cRNA probes that were prepared like the ${ }^{32} \mathrm{P}$-labeled probe used for Northern blots as described above, except for the substitution of $\left[\alpha^{-35} \mathrm{~S}\right]-\mathrm{UTP}(\sim 1,300 \mathrm{Ci} / \mathrm{mmol}$, Amersham Corp. $)$. A sense-strand, negative probe was formed by linearization with Smal (New England Biolabs) and transcription with Sp6 RNA polymerase (Promega Biotec, Madison, WI). The probes were hydrolyzed to $\sim 300$ $\mathrm{nt}$ in length (33). Hybridization was performed using $25 \mu \mathrm{l}$ of hybridization buffer $(32,33)$ containing $10^{7} \mathrm{cpm} /$ slide at $55^{\circ} \mathrm{C}$ overnight in a moist chamber. The concentration of the probe was $1.3 \mu \mathrm{g} / \mathrm{ml}$. The washing steps were carried out as described $(32,33)$. The dehydrated, air-dried sections were coated with Ilford K-5D emulsion and exposed for 9,21 , or $28 \mathrm{~d}$ in light-tight boxes at $4^{\circ} \mathrm{C}$. The slides were developed and the sections were stained with toluidine blue or hematoxylin-eosin and examined by light microscopy. Using the antisense and sense $\mathrm{Na}^{+}, \mathrm{K}^{+}$-ATPase $\alpha 1$ cRNA probes, consistent results with good labeling, low background, and good signal-noise ratio were obtained after 28 d of exposure.

\section{Results}

$\mathrm{Na}^{+}, \mathrm{K}^{+}$-ATPase enzyme activity. $\mathrm{Na}^{+}, \mathrm{K}^{+}$-ATPase activity in total lung homogenates from fetuses of diabetic rats at $21 \mathrm{~d}$ of gestation was $60 \%$ of the normal value $(P<0.001)$ (Fig. 1). The enzyme activity of normal pups at neonatal day 1 was not significantly different from the value measured at fetal day 21 in normals (Fig. 1). One day after birth and removal from the diabetic milieu, the enzyme activity was not significantly different in the diabetic groups compared to the controls (Fig. 1).

Northern blot analysis. Total cellular RNA was prepared from lung tissue of fetuses from normal and diabetic mothers, and the $\sim 4.5 \mathrm{~kb} \mathrm{Na}^{+}, \mathrm{K}^{+}$-ATPase $\alpha 1$ mRNA band was detected on Northern blots with an equal loading of $20 \mu \mathrm{g}$ of RNA per lane. The steady-state level of $\mathrm{Na}^{+}, \mathrm{K}^{+}$-ATPase $\alpha 1$ mRNA in fetal lungs from diabetic mothers (Fig. 2, lane 2) was $59 \%( \pm 16 \%$ SEM, $n=6)$ that of fetuses of normals at day 21 of gestation (Fig. 2, lane 1), whereas there was no difference between the two groups of neonatal animals (Fig. 2, lanes 3 and 4). Densitometry was performed on autoradiographs after 24-h exposures, at which time the signals were strong but saturation of the film emulsion had not occurred (Fig. $2 b$ ). The differences could not be ascribed to differential degradation of the RNA because the recovery of the $28 \mathrm{~S}$ and $18 \mathrm{~S}$ rRNAs, as well as similar fine bands between these two markers, seen on acri-

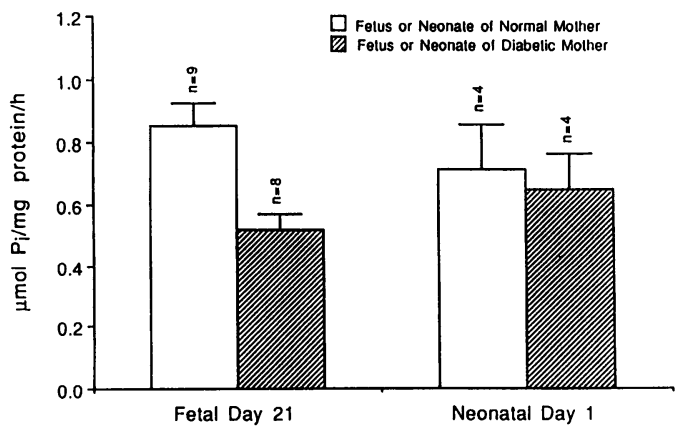

Figure 1. Ouabain-sensitive $\mathrm{Na}^{+}, \mathrm{K}^{+}$-ATPase activity in lung homogenates of fetuses and neonates of normal and diabetic mothers. Data are mean values \pm SEM for the number of experiments shown above the bars. Tissue samples were pooled in each experiment from a litter (fetal) or part of a litter (neonatal), and each pool was assayed in triplicate. The difference between the fetal values was statistically significant $(P<0.001)$. 

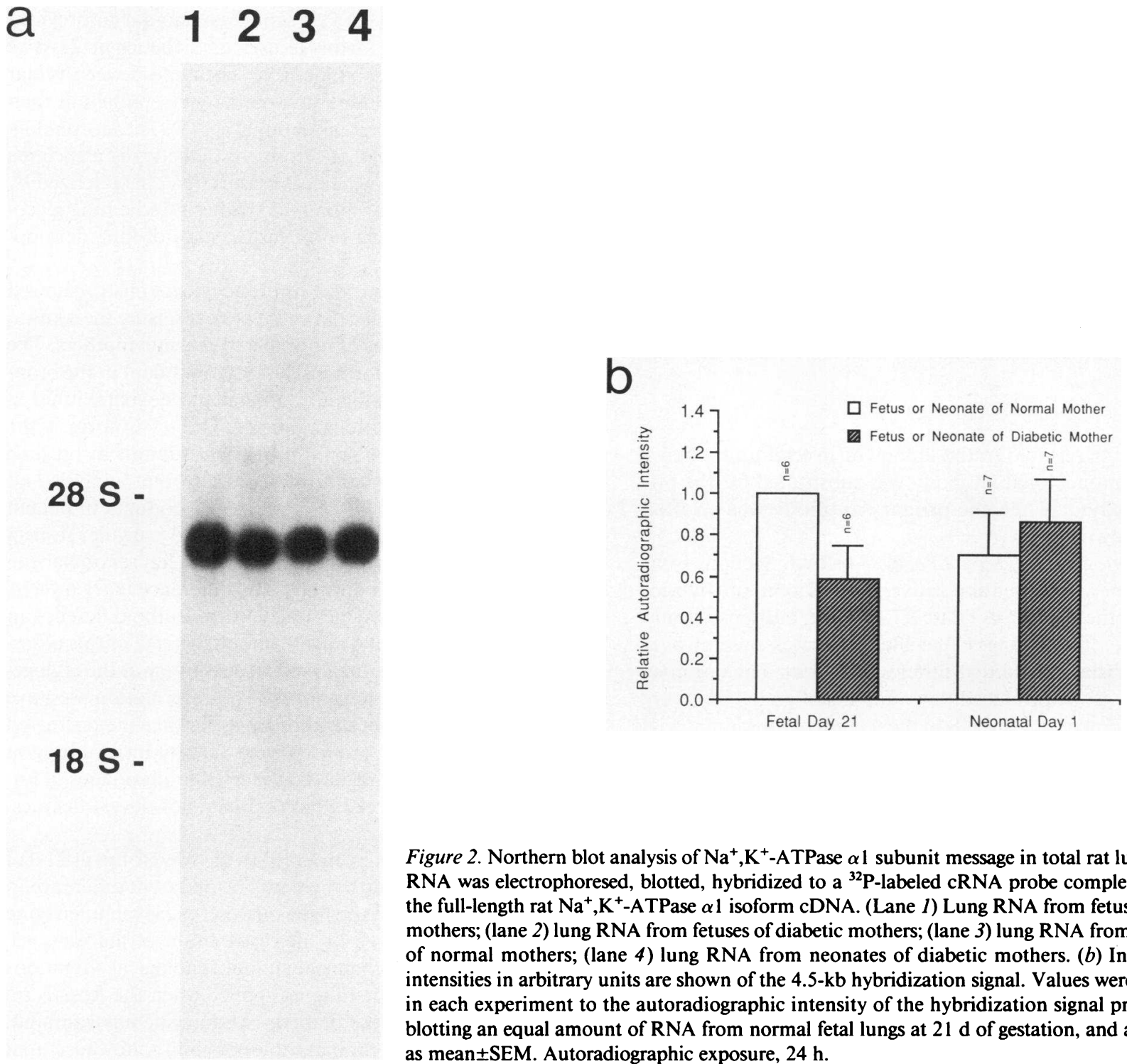

Figure 2. Northern blot analysis of $\mathrm{Na}^{+}, \mathrm{K}^{+}$-ATPase $\alpha 1$ subunit message in total rat lung RNA. (a) RNA was electrophoresed, blotted, hybridized to a ${ }^{32} \mathrm{P}$-labeled cRNA probe complementary to the full-length rat $\mathrm{Na}^{+}, \mathrm{K}^{+}$-ATPase $\alpha 1$ isoform cDNA. (Lane 1) Lung RNA from fetuses of normal mothers; (lane 2) lung RNA from fetuses of diabetic mothers; (lane 3) lung RNA from neonates of normal mothers; (lane 4) lung RNA from neonates of diabetic mothers. (b) Integrated intensities in arbitrary units are shown of the $4.5-\mathrm{kb}$ hybridization signal. Values were normalized in each experiment to the autoradiographic intensity of the hybridization signal produced by blotting an equal amount of RNA from normal fetal lungs at $21 \mathrm{~d}$ of gestation, and are expressed as mean $\pm \mathrm{SEM}$. Autoradiographic exposure, $24 \mathrm{~h}$.

dine orange-stained gels indicated that the RNAs were intact and the lanes equally loaded (data not shown).

Morphometry. The histology of lung tissue of fetuses from normal mothers at $21 \mathrm{~d}$ of gestation was different from that of fetuses of diabetic mothers. The structure of normal lung at fetal day 21 (terminal-sac period in lung development) was characterized by a well-developed bronchial-bronchiolar system and the flattening of epithelial cells lining the alveoli (Fig. 3 $a$; and Fig. 5, $a-d$ ). Lungs from the fetuses of diabetic rats at the same age resembled the earlier, canalicular stage of development with thick septa between the glandlike air spaces that were lined by cuboidal epithelial cells (Fig. 3, $b$ and $c$; Fig. 6, $a-d)$. By $1 \mathrm{~d}$ of age, the histology of the lungs was not different in neonates of normal and diabetic mothers (Fig. 7, $a-e$ ).

Morphometry performed on samples of rat lung tissue at fetal day 21 (Table I) showed that the area occupied by tall, columnar, bronchial, epithelial cells was not different in the normal and diabetic conditions. However, the percentage of epithelial and mesenchymal cells that form the incipient alveolar area was significantly larger in fetal lungs of diabetics com- pared to the normals $(P<0.001)$. The area designated as airspace was correspondingly smaller in fetal lungs of diabetics $(P$ $<0.001)$.

Localization of $\mathrm{Na}^{+}, \mathrm{K}^{+}$-ATPase $\alpha \mathrm{l}$ antigen. To confirm the validity of immunodetection of $\mathrm{Na}^{+}, \mathrm{K}^{+}$-ATPase using the monoclonal antibody (31), we carried out studies on normal rat kidney, which is known to be an abundant source of the sodium pump $\alpha 1$ isoenzyme $(19,34)$. Immunoperoxidase staining was observed in the cortex of the rat kidney, and the antigen was found in the distal convoluted tubules and the thick ascending limbs of the loops of Henle, whereas the proximal tubules stained weakly (data not shown).

In the fetal lung immunoperoxidase staining revealed $\mathrm{Na}^{+}, \mathrm{K}^{+}$-ATPase immunoreactive material at the basolateral membranes of cells. The most intense staining reaction occurred in the epithelial cells of bronchioli in fetal lungs of normal and diabetic mothers at $21 \mathrm{~d}$ of gestation (Fig. 3, $a$ and $b$, bronchioli of fetuses of diabetic mothers, not shown) and in the cuboidal cells lining of future alveoli in the fetuses of both normal mothers and diabetics (Fig. 3, $b$ and $c$ ). 
Table I. Morphometry of Fetal Lungs of Normal and Diabetic Mothers

\begin{tabular}{lccc}
\hline $\begin{array}{c}\text { Experimental } \\
\text { conditions }\end{array}$ & $\begin{array}{c}\text { Bronchiolar } \\
\text { epithelial cells }\end{array}$ & $\begin{array}{c}\text { Epithelial and } \\
\text { mesenchymal cells } \\
\text { in alveolar area }\end{array}$ & Air spaces \\
\hline & $\%$ & $\%$ & $\%$ \\
Normal & $4.9 \pm 0.38$ & $57.6 \pm 1.01$ & $37.5 \pm 2.30$ \\
Diabetic & $4.8 \pm 0.45$ & $73.3 \pm 1.20^{*}$ & $20.8 \pm 2.60^{*}$ \\
\hline
\end{tabular}

Data are expressed as the mean $\pm \mathrm{SEM}$ of $100.5-\mu \mathrm{m}$ sections evaluated from 10 lungs of three litters of each group at $21 \mathrm{~d}$ of gestation. * These values are significantly different from those of normals with $P<0.001$.

No staining resulted in the kidney or in fetal lung when a nonspecific monoclonal antibody was substituted for the primary antibody or when the primary antibody was omitted (data not shown).

Localization of $\mathrm{Na}^{+}, \mathrm{K}^{+}$-ATPase $\alpha 1 \mathrm{mRNA}$. Sections from adult rat kidney were used as positive controls for in situ hybridization with the $\mathrm{Na}^{+}, \mathrm{K}^{+}$-ATPase $\alpha 1$ positive, antisense-strand cRNA probe. The strongest specific signal was present over cells of the distal convoluted tubules (Fig. $4 a$ ). The negative, sense-strand probe produced low numbers of grains that were evenly distributed over all cells in the section of the kidney (Fig. 4 b).

In normal fetal lungs at $21 \mathrm{~d}$ of gestation a large number of grains was present above undifferentiated cuboidal cells lining the presumptive alveoli (Fig. $5 a$ ). The strongest specific signal was detected above columnar epithelial cells of large air-conducting structures (Fig. 5 b). Hybridization with the negative, sense-strand probe yielded homogeneous, low-level labeling on the lung sections (Fig. 5, $c$ and $d$ ).

The lungs from fetuses of diabetic rats at the same age gave a strong specific signal over cuboidal cells lining the immature alveoli (Fig. $6 a$ ). The cells constituting the thick walls between the less-expanded airspaces showed fewer grains above them (Fig. $6 a$ ). Strong labeling was also seen above bronchial-bronchiolar epithelia (Fig. 6 b). A small number of silver grains was distributed evenly over the lung section when the negative probe was used (Fig. 6, $c$ and $d$ ).

By $1 \mathrm{~d}$ of age the distribution of the message was similar in lungs of neonates of normal and diabetic mothers. Both showed strong positive signals above bronchial and bronchiolar structures and a decrease from fetal day 21 in silver grains present above cells lining alveoli. Fig. 7, $a-c$, represents typical hybridization patterns using the positive, antisense-strand probe on neonatal lung from a diabetic mother at $1 \mathrm{~d}$ of age. No specific signal was generated using the negative, sense-strand probe (Fig. 7, $d$ and $e$ ).

\section{Discussion}

In the present study we tested the hypothesis that the delay of pulmonary maturation of fetuses from diabetic mothers causes an impairment in $\mathrm{Na}^{+}, \mathrm{K}^{+}$-ATPase mRNA expression and in enzyme activity. This reduced ion transport function would then be directly associated with the pathological sequelae of maternal diabetes.
The morphometric data presented are similar to previous observations that lungs from fetuses of diabetics at $21 \mathrm{~d}$ of gestation contain more abundant mesenchyme, fewer alveolar ducts and less well-differentiated pulmonary epithelium than normal animals of the same gestational age (7). The morphological immaturity of lungs of fetuses of diabetics is associated with a delay in lung biochemical maturation characterized by decreased surfactant phospholipid synthesis and a lung glycogen content more typical of an earlier stage of lung development $(6,7)$.

In situ hybridization and immunocytochemistry showed that there was no difference in cell types expressing the sodium pump in lungs of fetuses of normal and diabetic mothers. The $\mathrm{Na}^{+}, \mathrm{K}^{+}$-ATPase $\alpha 1$ isoform mRNA was abundant in the bronchiolar and alveolar epithelium of fetal and neonatal lungs in both normal and diabetic conditions. The $\alpha 1$ isoform is the predominant subtype of sodium pump $\alpha$ subunit in rat lung $(34,35)$. On the other hand, the Northern blot analysis and enzyme assay for $\mathrm{Na}^{+}, \mathrm{K}^{+}$-ATPase gene products indicated lower steady-state levels of $\alpha 1$ message and enzyme, respectively, in extracts of lung tissue derived from fetuses of diabetic mothers compared with normals. The difference in $\alpha 1 \mathrm{mRNA}$ (59\% of control) was practically identical to the difference in enzyme activity ( $60 \%$ of control), although some of this difference in activity may be due to reduced recovery of the endogenous enzyme in diabetic samples. The information we have presented on cellular localization suggests that the decreased $\mathrm{Na}^{+}, \mathrm{K}^{+}$-ATPase mRNA and enzyme activity in fetal lung of diabetic mothers likely relates to the relative abundance of immature mesenchymal cells which exhibit a low level of expression of $\mathrm{Na}^{+}, \mathrm{K}^{+}$-ATPase.

Despite the differences observed in the two groups at $21 \mathrm{~d}$ of gestation, at $1 \mathrm{~d}$ after birth there was no apparent difference in the lung morphology at the light microscopic level, in enzyme activity, in mRNA level, or the distribution of the message. Thus in the rat the biochemical and morphological alterations seen in the fetal diabetic lung normalize when the fetus is removed by birth from the diabetic intrauterine environment. These results do not eliminate the possibility, however, that these changes occur in utero between gestational day 21 and birth on day 22 .

The lung also undergoes functional maturation during the immediate perinatal period (36-38). In preparation for respiration lung fluid must be cleared from the airways at the time of birth. Some of the fluid is drained, but most is removed by an active process that is likely associated with active $\mathrm{Na}^{+}$and $\mathrm{Cl}^{-}$ transport by apical $\mathrm{Na}^{+}$channels and $\mathrm{Cl}^{-}$channels, as well as the homeostatic function of the $\mathrm{Na}^{+}, \mathrm{K}^{+}$-ATPase of the basolateral membranes of the respiratory epithelium. The importance of the $\mathrm{Na}^{+}$pump is supported by experiments showing that inhibition by ouabain of ${ }^{86} \mathrm{Rb}^{+}$uptake, a measure of $\mathrm{K}^{+}$ flux, causes a corresponding increase in luminal fluid in fetal and neonatal lung (17). The observation that $\mathrm{Na}^{+}$pump $\alpha 1$ and $\beta$ mRNAs in lung increase at birth also supports the hypothesis that active ion transport across pulmonary epithelium facilitates fluid absorption (34). The delay in lung fluid clearance in human premature newborns has been associated with decreased $\mathrm{Na}^{+}, \mathrm{K}^{+}$-ATPase activity of the tissue (17).

We have found a high level of expression of $\mathrm{Na}^{+}, \mathrm{K}^{+}$-ATPase in the bronchial-bronchiolar epithelium, and this provides further support for a role for the $\mathrm{Na}^{+}$-pump in lung fluid ab- 

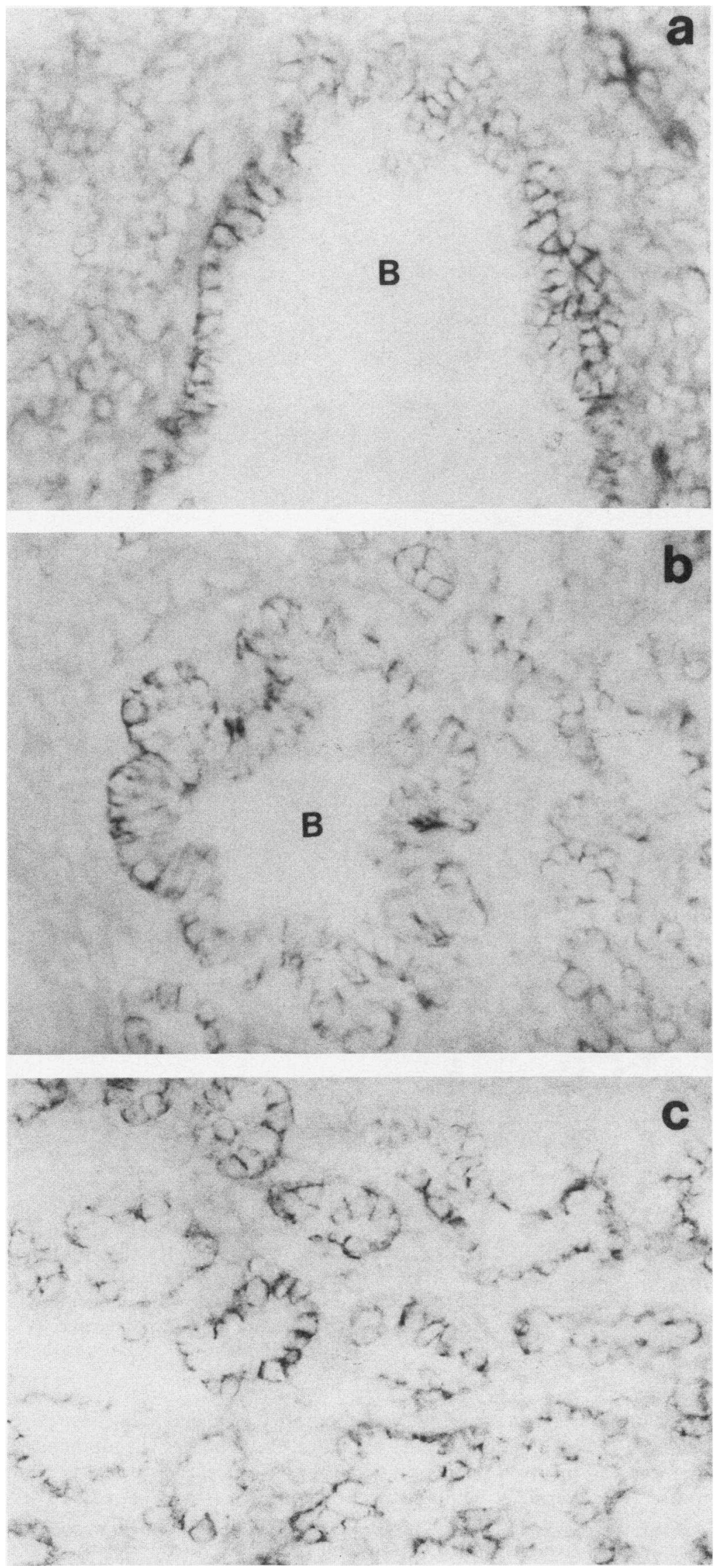

Figure 3. Immunoperoxidase localization of $\mathrm{Na}^{+}, \mathrm{K}^{+}$ATPase $\alpha 1$ antigen in fetal rat lungs of $(a, b)$ normal and $(c)$ diabetic mothers at $21 \mathrm{~d}$ of gestation. $B$, lumen of bronchiolus. Magnification, 600. Compare the bronchiolar and alveolar staining for the protein in $a$ and $b$ to the localization of the mRNA in Fig. 5, $a$ and $b$; and the alveolar staining in $c$ to Fig. $6 a$. 

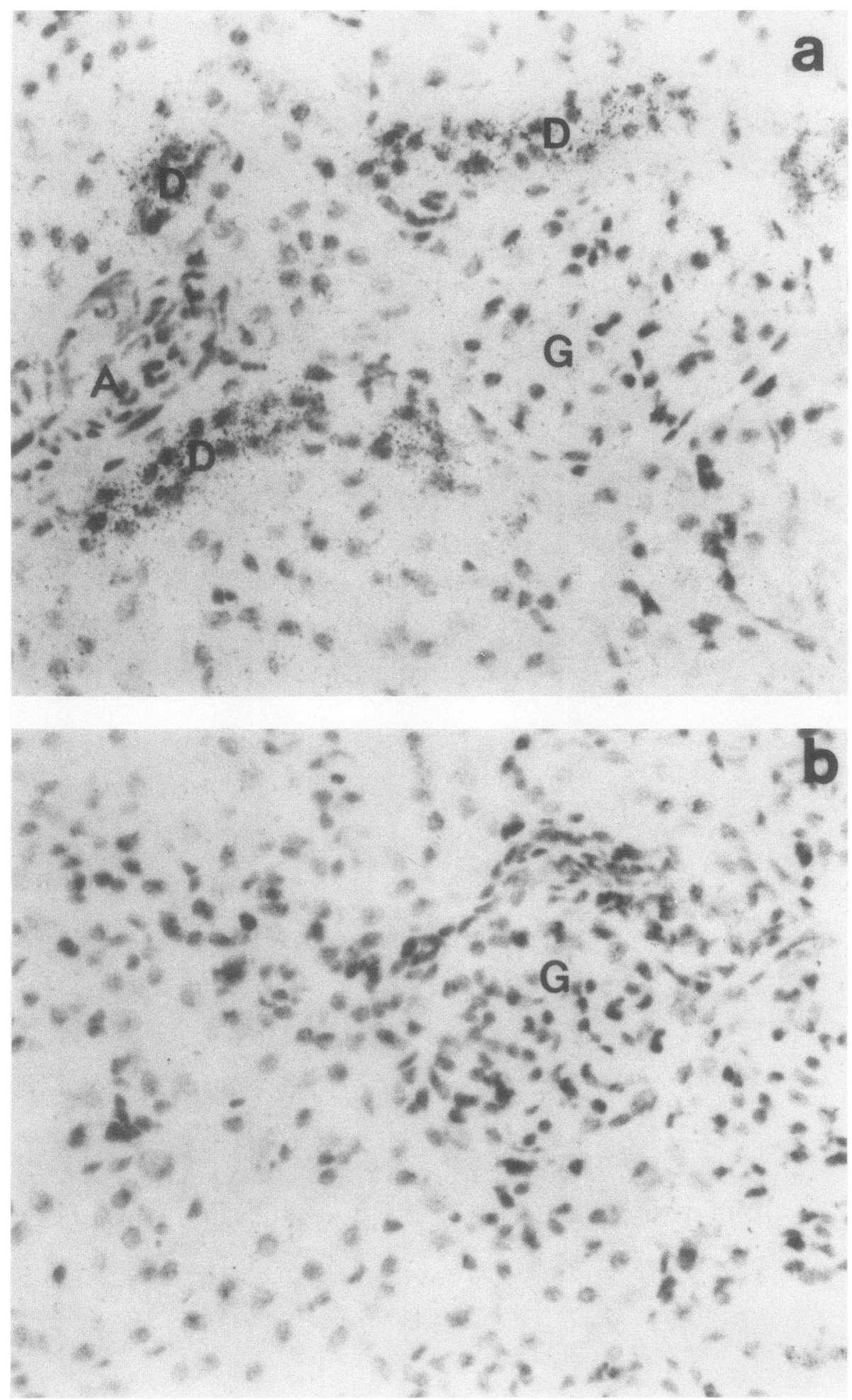

Figure 4. In situ hybridization of $\mathrm{Na}^{+}, \mathrm{K}^{+}$-ATPase $\alpha 1$ isoform mRNA in adult rat kidney. (a) Positive cRNA probe. (b) Negative cRNA probe. Several structures are identified, such as distal convoluted tubules $(D)$, glomeruli $(G)$, and an arteriole $(A)$. Exposure time, 28 d. Magnification, 300 . sorption, particularly by these cells. We have shown that the maternal diabetic state and the concomitant fetal hyperglycemia are also associated with a striking decrease in the concentration of placental epidermal growth factor receptors (39). Epidermal growth factor has been shown to increase $\mathrm{Na}^{+}, \mathrm{K}^{+}$-ATPase activity (40). Therefore, lung fluid absorption and other aspects of lung maturation may also be influenced by epidermal growth factor and other peptide growth factors.
The biochemical and morphological alterations seen in fetal lungs of diabetics normalize by $1 \mathrm{~d}$ of age. The mechanisms involved in this dramatic reversal of pathology are unclear. Perinatal fluid and electrolyte transport may be reduced secondary to the increased mesenchymal cell content, or, alternatively, the lack of thinning of these cells may result from a reduction in epithelial cells of a transport function distinct from the $\mathrm{Na}^{+}$pump. Further experiments on the ion channel 

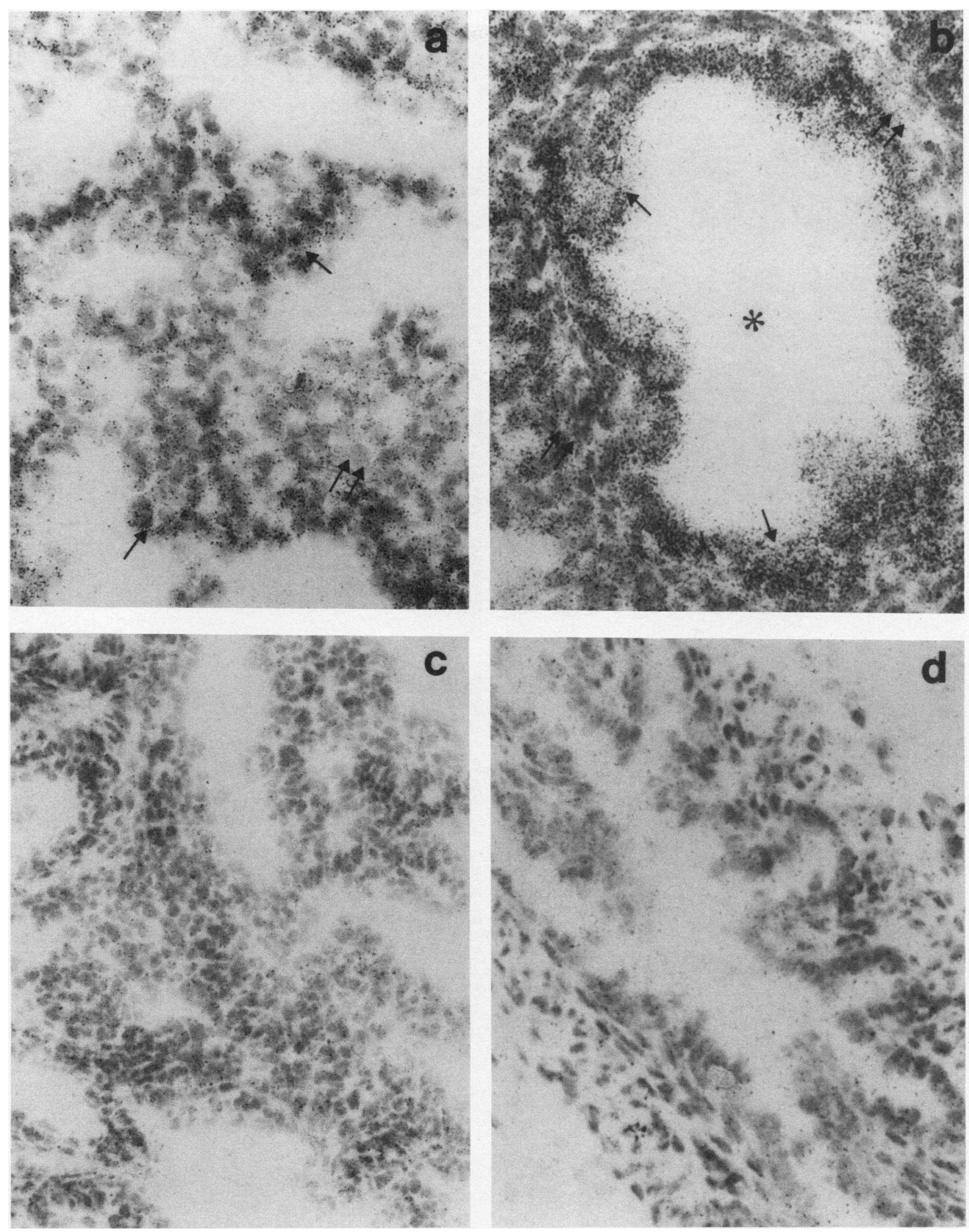

Figure 5. Localization of $\mathrm{Na}^{+}, \mathrm{K}^{+}$-ATPase $\alpha 1$ isoform mRNA in normal fetal lungs at $21 \mathrm{~d}$ of gestation. $(a, b)$ Positive cRNA probe. $(c, d)$ Negative probe. An accumulation of autoradiographic grains over regions of the lung containing incipient alveoli (arrows) but not mesenchymal cells (double arrows) is shown in $a$. Specific grains over regions containing a bronchiolus (arrows), but not over associated mesenchyme (double arrows) are shown in $b$. The lumen of a bronchiolus is indicated $\left({ }^{*}\right)$. Exposure time, $28 \mathrm{~d}$. Magnification, 600. 

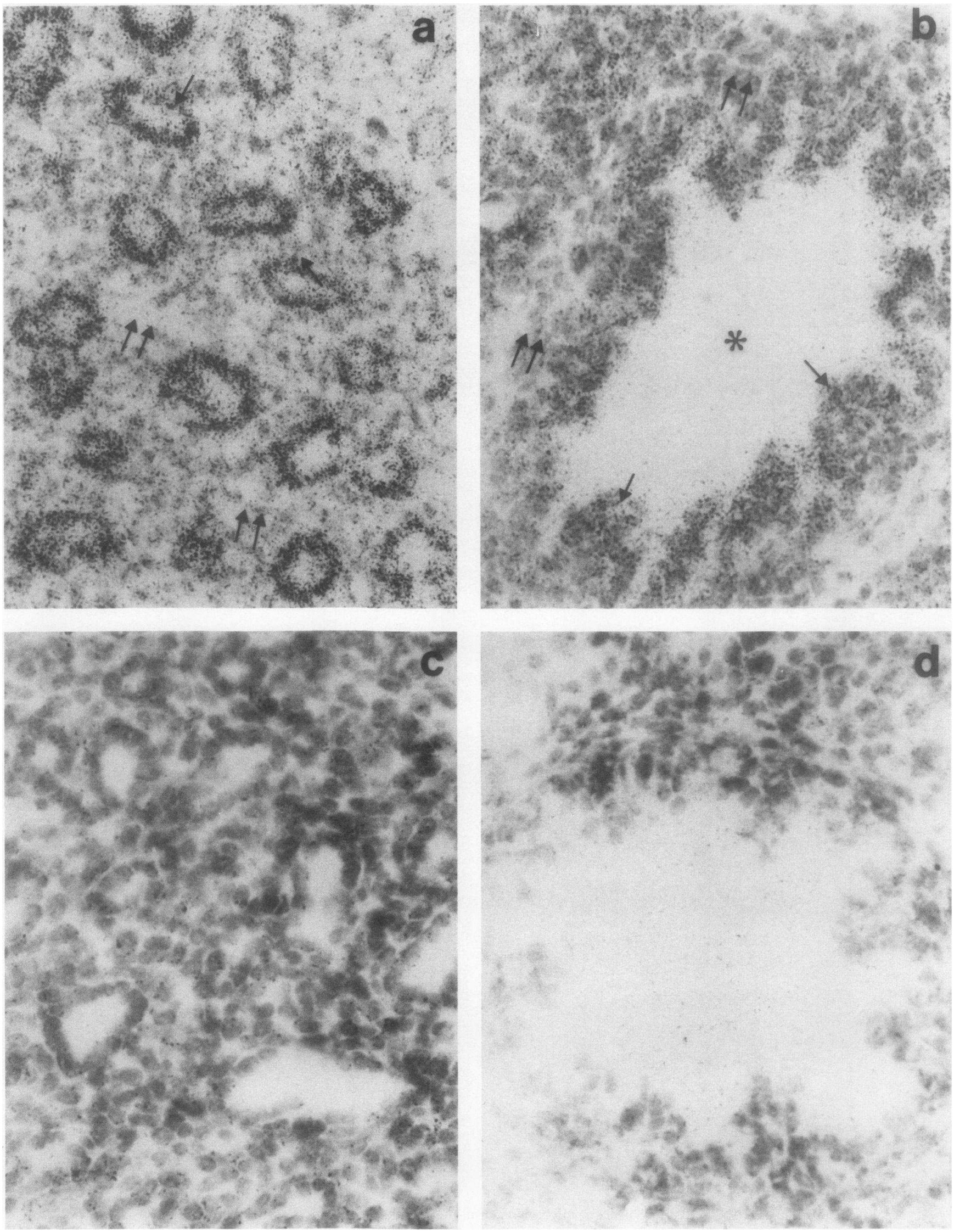

Figure 6. Localization of $\mathrm{Na}^{+}, \mathrm{K}^{+}$-ATPase $\alpha 1$ isoform mRNA in fetal lung from a diabetic mother at $21 \mathrm{~d}$ of gestation. (a,b) Positive cRNA probe. $(c, d)$ Negative cRNA probe. Arrows and asterisk, same as in legend to Fig. 5. Exposure time, $28 \mathrm{~d}$. Magnification, 600. 

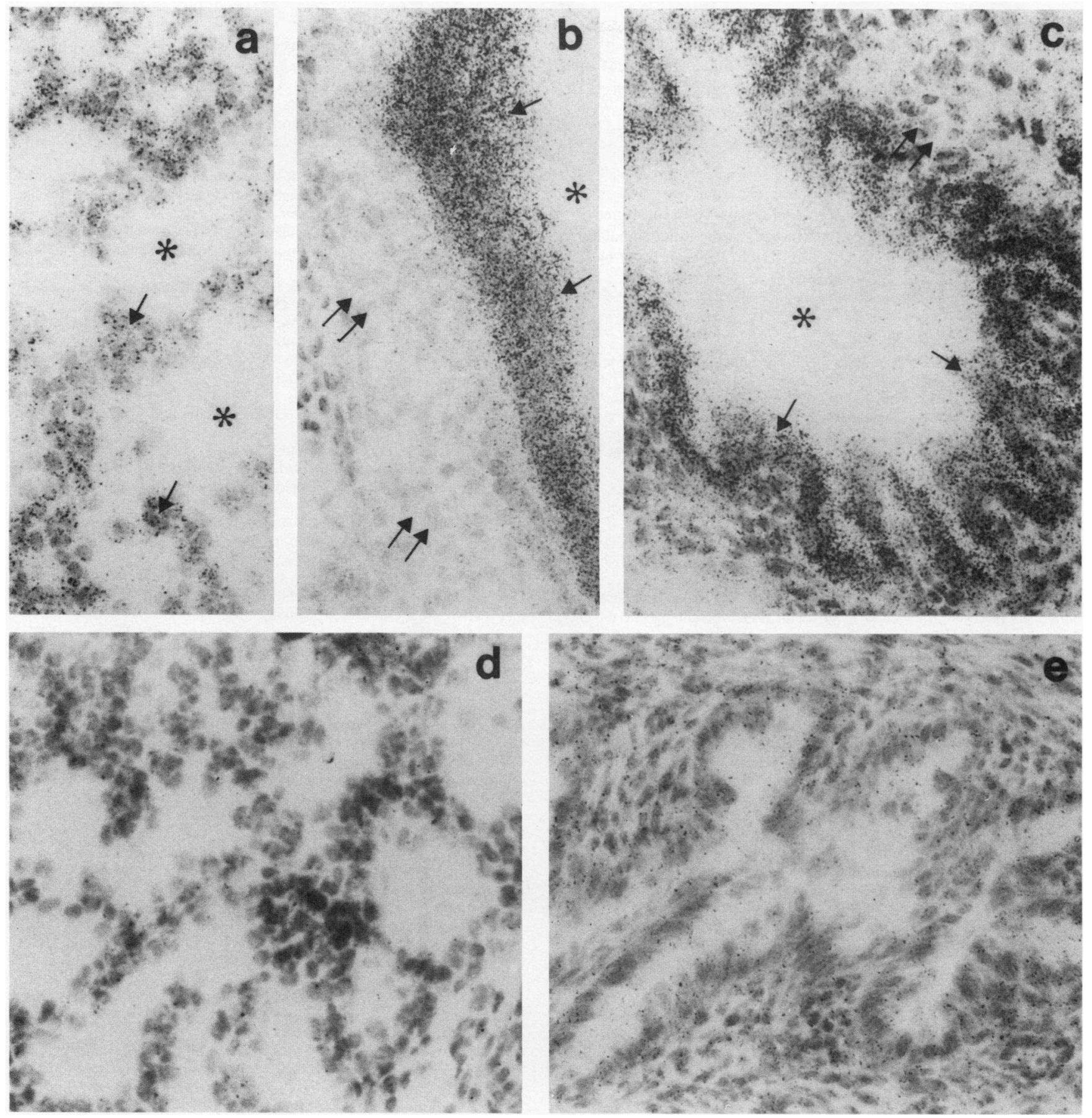

Figure 7. Localization of $\mathrm{Na}^{+}, \mathrm{K}^{+}$-ATPase $\alpha 1$ isoform mRNA in neonatal lung $1 \mathrm{~d}$ after birth from a diabetic mother. (a-c) Positive cRNA probe; $(d, e)$ negative cRNA probe. Regions containing alveolar epithelium (arrows) are shown in $a$. The epithelium of a larger bronchus (arrows) and associated mesenchyme (double arrows) are depicted in $b$. A bronchiolus and some mesenchyme (double arrow) are included in $c$. The lumens of airways are denoted by $\left({ }^{*}\right)$. Exposure time, $28 \mathrm{~d}$. Magnification, 600 .

and transporter activities in membranes of isolated cell populations from lungs of these animals may point to specific defects in fetuses of diabetic mothers, and the effects of altered extracellular glucose could be discerned from those of insulin and other hormones and growth factors. We have found that insulin levels are low relative to glucose levels in fetuses of diabetic rats (8). There is evidence from studies with diabetic models in monkey (41) and sheep (42), on the other hand, for the impor- tance of fetal hyperinsulinemia in lung pathology. The influences of a number of steroid hormones and other peptide hormones and growth factors on fetal lung maturation are well studied (reviewed in references 43 and 44). After parturition and the onset of breathing in the newborn rabbit, $4 \mathrm{~h}$ is sufficient to complete the lung's expansion and allow no difference to be observed histologically between newborn and adult lung (45). Our data provide further evidence that maternal diabetes 
changes the perinatal lung morphology, show that $\mathrm{Na}^{+}, \mathrm{K}^{+}$-ATPase is maintained at high levels in bronchiolar and alveolar epithelial cells, and suggest that other functions involved in pulmonary fluid clearance at birth are altered in developing lungs of diabetic mothers.

\section{Acknowledgments}

We would like to thank E. Benz for the generous provision of the cDNA clone, R. Dowin for fine technical assistance in immunocytochemistry, and K. Sweadner for the kind gift of the monoclonal antibody. This work was supported by grant DK 17389 to J. D. Jamieson and grant HL30119 to J. B. Warshaw.

\section{References}

1. Gellis, S. S., and D. Y.-Y. Hsia. 1959. The infant of the diabetic mother Am. J. Dis. Child. 97:1-41.

2. Robert, M. F., R. K. Neff, J. P. Hubbell, W. H. Taeusch, and M. E. Avery. 1976. Association between maternal diabetes and the respiratory-distress syndrome in the newborn. $N$. Engl. J. Med. 294:357-360.

3. Bourbon, J. R., and P. M. Farrell. 1985. Fetal lung development in the diabetic pregnancy. Pediatr. Res. 19:253-267.

4. Sosenko, I. R. S., E. E. Lawson, V. Demottaz, and I. D. Frantz. 1980 Functional delay in lung maturation in fetuses of diabetic rabbits. J. Appl. Physiol. 48:643-647.

5. Bose, C. L., P. N. Mame, A. J. D'Ercole, and E. E. Lawson. 1980. Delayed fetal pulmonary maturation in rabbit model of the diabetic pregnancy. J. Clin. Invest. 66:220-226.

6. Gewolb, I. H., C. Barett, C. M. Wilson, and J. B. Warshaw. 1982. Delay in pulmonary glycogen degradation in fetuses of streptozotocin-diabetic rats. $\mathrm{Pe}$ diatr. Res. 16:869-873.

7. Gewolb, I. H., S. A. Rooney, C. Barett, L. D. Jugleson, D. Light, C. M Wilson, G. J. Walker-Smith, I. Gross, and J. B. Warshaw. 1985. Delayed pulmonary maturation in the fetus of the streptozotocin-diabetic rat. Exp. Lung Res. $8: 141-151$

8. Gewolb, I. H., C. Barett, and J. B. Warshaw. 1983. Placental growth and glycogen metabolism in streptozotocin diabetic rats. Pediatr. Res. 17:587-591.

9. Moxley, M. A., and W. J. Longmore. 1975. Studies on the effects of alloxan in streptozotocin-induced diabetes on lipid metabolism in the isolated lung. Life Sci. 17:921-926.

10. Moxley, M. A., and W. J. Longmore. 1977. Effect of experimental diabetes on lipid metabolism in the isolated perfused rat lung. Biochim. Biophys. Acta. 488:218-224.

11. Bourbon, J. R., M. Rientort, M. J. Engle, and P. M. Farel. 1982. Utilization of glycogen for phospholipid synthesis in fetal rat lung. Biochim. Biophys. Acta. 712:382-389.

12. Erickson, U. J., D. Tyden, and C. Berne. 1983. Development of phosphatidylglycerol biosynthesis in the lungs of diabetic rats. Diabetologia. 24:202-206.

13. Tsai, M. Y., M. W. Josephson, and J. Donhowe. 1983. Delayed pulmonary phosphatidylglycerol synthesis and reversal by prenatal dexamethasone in fetuses of streptozotocin-diabetic mothers. Exp. Lung Res. 4:315-323.

14. Mescher, E. J., A. C. G. Platzker, P. L. Ballard, J. A. Kitterman, J. A. Clements, and W. H. Tooley. 1975. Ontogeny of tracheal fluid, pulmonary surfactant, and plasma corticoids in the fetal lambs. J. Appl. Physiol. 39:1017-1021

15. Kitterman, J. A., P. L. Ballard, J. A. Clements, E. J. Mescher, and W. H Tooley. 1979. Tracheal fluid in fetal lambs: spontaneous decrease prior to birth J. Appl. Physiol. 47:985-989.

16. Bland, D. R., T. N. Hansen, C. M. Haberkern, M. A. Bressack, T. A. Hasinski, J. U. Raj, and R. B. Goldberg. 1982. Lung liquid balance in lambs before and after birth. J. Appl. Physiol. 53:992-1004.

17. Bland, R. D., and C. A. R. Boyd. 1986. Cation transport in lung epithelial cells derived from fetal, newborn and adult rabbits. J. Appl. Physiol. 62:507-515.

18. Oliver, R. E., E. E. Schneeberger, and D. V. Walters. 1981. Epithelial solute permeability, ion transport, and tight junction morphology in the developing lung of the fetal lamb. J. Physiol. (Lond.). 315:395-412.
19. Cantley, L. C. 1981. Structure and mechanism of the (Na,K)-ATPase. Curr. Top. Bioenerget. 11:201-237.

20. Stekhoven, S. F., and S. L. Bonting. 1981. Transport adenosine triphosphatases: properties and functions. Physiol. Rev. 61:1-76.

21. Stahl, W. L. 1986. The Na,K-ATPase of nervous tissue. Neurochem. Int. 8:449-476.

22. Rozengurt, E., and L. A. Heppel. 1975. Serum rapidly stimulates oubainsensitive ${ }^{86} \mathrm{Rb}^{+}$influx in quiescent 3 T3 cells. Proc. Natl. Acad. Sci. USA. 72:44924495 .

23. Smith, R. L., I. G. Macara, R. Levenson, D. Housman, and L. Cantley. 1982. Evidence that a $\mathrm{Na}^{+} / \mathrm{Ca}^{2+}$ antiport system regulates murine erythroleukemia cell differentiation. J. Biol. Chem. 257:773-780.

24. Rosoff, P. M., and L. C. Cantley. 1983. Increasing the cellular $\mathrm{Na}^{+}$concentration induces differentiation in a pre-B lymphocyte cell line. Proc. Natl. Acad. Sci. USA. 80:7547-7550.

25. Skou, J. C. 1965. Enzymatic basis for active transport of $\mathrm{Na}^{+}$and $\mathrm{K}^{+}$ across cell membrane. Physiol. Rev. 45:596-617.

26. Fiske, C. H., and Y. Subbarow. 1925. The colorimetric determination of phosphorus. J. Biol. Chem. 66:375-400.

27. Lowry, O. H., N. J. Rosebrough, A. L. Farr, and R. J. Randall. 1951. Protein measurement with the Folin phenol reagent. J. Biol. Chem. 193:265-275.

28. Chirgwin, J. M., A. E. Przbyla, R. J. MacDonald, and W. J. Rutter. 1979. Isolation of biologically active ribonucleic acid from sources enriched in ribonuclease. Biochemistry. 18:5294-5299.

29. Maniatis, T., E. F. Fritsch, and J. Sambrook. 1982. Molecular Cloning: A Laboratory Manual. Cold Spring Harbor Laboratory, Cold Spring Harbor, NY.

30. Weibel, R. E. 1969. Stereological principles for morphometry in electron microscopic cytology. Int. Rev. Cytol. 26:235-302.

31. Felsenfeld, D. P., and K. J. Sweadner. 1988. Fine specificity mapping and topography of an isoenzyme-specific epitope of the Na, K-ATPase catalytic subunit. J. Biol. Chem. 263:10932-10942.

32. Cox, K. H., D. V. DeLeon, L. M. Angerer, and R. C. Angerer. 1984 Detection of mRNA in sea urchin embryos by in situ hybridization using asymmetric RNA probes. Dev. Biol. 101:485-502.

33. Awgulewitsch, A., M. F. Utset, C. P. Hart, W. McGinnis, and F. H. Ruddle. 1986. Spatial restriction in expression of a mouse homoeo box locus within the central nervous system. Nature (Lond.). 320:328-335.

34. Orlowski, J., and J. B. Lingrel. 1988. Tissue-specific and developmental regulation of rat $\mathrm{Na}, \mathrm{K}-\mathrm{ATPase}$ catalytic alpha isoform and beta subunit mRNAs. J. Biol. Chem. 263:10436-10442.

35. Schneider J. W., R. W. Mercer, M. Gilmore-Hebert, M. F. Utset, C. Lay, A. Greene, and E. J. Benz, Jr. 1988. Tissue specificity, localization in brain, and cell-free translation of mRNA encoding the $\alpha 3$ isoform of $\mathrm{Na}^{+}, \mathrm{K}^{+}$-ATPase. Proc Natl. Acad. Sci. USA. 85:284-288.

36. Alcorn, D. G., I. G. S. Alexander, J. E. Moloney, B. C. Ritchie, and A. M Walker. 1974. Morphological development of the lung: a review. Aust. Pediatr. J. 10:189-198

37. Ten Have-Opbroek, A. A. W. 1981. The development of the lung in mammals: an analysis of concepts and findings. Am. J. Anat. 162:201-219.

38. Burri, P. H. 1984. Fetal and post-natal development of the lung. Annu. Rev. Physiol. 46:617-628.

39. Sissom, J. F. W. K. Stenzel, and J. B. Warshaw, 1987. Decreased binding of epidermal growth factor in placentas from streptozotocin diabetic rats. J. Clin Invest. 80:241-247.

40. Yarden, Y., A. B. Schreiber, and J. Schlessinger. 1982. A non-mitogenic analogue of epidermal growth factor induces early responses mediated by epidermal growth factor. J. Cell Biol. 92:687-693.

41. Rooney, S. A., A. J. Chu, I. Gross, P. A. Marino, R. Schwartz, P. Seghal, D. B. Singer, J. B. Susa, J. B. Warshaw, and C. M. Wilson. 1983. Lung surfactant in the hyperinsulinemic fetal monkey. Lung. 161:313-317.

42. Warburton, D. C. D. Lew, and A. C. G. Platzker. 1981. Primary hyperinsulinemia reduces surface active material flux in tracheal fluid of fetal lambs Pediatr. Res. 15:1422-1424.

43. Rooney, S. A. 1985. The surfactant system and lung phospholipid biochemistry. Am. Rev. Respir. Dis. 131:439-460.

44. Ballard, P. L. 1989. Hormonal regulation of pulmonary surfactant. Endocr. Rev. 10:165-181.

45. Kikkawa, Y., E. K. Motoyama, and L. Gluck. 1968. Study of the lungs of fetal and newborn rabbits. Am. J. Pathol. 52:177-209. 